\title{
Anaerobic cometabolism of fruit and vegetable wastes using mammalian fecal inoculums: Fast assessment of biomethane production
}

\author{
M. Islas-Espinoza ${ }^{\text {a }}$, A. de las Heras ${ }^{\text {b }}$, J.C. Vázquez-Chagoyán ${ }^{\text {c }}$, A.Z.M. Salem ${ }^{\text {c, * }}$ \\ a InterAmerican Center for Water Resources, Faculty of Engineering, Mexico State University, Mexico \\ ${ }^{\mathrm{b}}$ Independent Researcher, Burgos, Spain \\ ${ }^{\mathrm{c}}$ Facultad de Medicina Veterinaria y Zootecnia, Universidad Autónoma del Estado de México, Mexico
}

\section{A R T I C L E I N F O}

\section{Article history:}

Received 6 September 2016

Received in revised form 25 September 2016

Accepted 29 September 2016

Available online 30 September 2016

\section{Keywords:}

Anaerobic digestion

Cometabolism

Initiation

Rapid assessment

Methane

Kinetics

\begin{abstract}
A B S T R A C T
Anaerobic digestion (AD) is a biological process which produces biomethane as energy source, using waste as substrate. Cometabolism is a novel way to enhance liquid AD, via augmenting the biodiversity of inoculums, especially in the hitherto little-studied 96-h initiation period critical to AD startup. Dog, horse and sheep feces were used as sources of inoculum and mixed with fruit and vegetable waste (FVW) and water. Thermophilic $\left(55^{\circ} \mathrm{C}\right)$, mesophilic $\left(39^{\circ}\right)$ and psychrophilic $\left(25^{\circ} \mathrm{C}\right) \mathrm{AD}$ conditions were tested. As inoculum and water quantities alter the abundance and diversity of the anaerobic communities, 1:1 and 1:4 ratios of FVW feedstock to inoculum solutions were compared. Live Saccharomyces cerevisiae was supplemented as probiotic in the anaerobic reactors. Biogas, $\mathrm{CO}_{2}$ and $\mathrm{CH}_{4}$ were measured as well as digestion of FVW. Results showed consistently more $\mathrm{CH}_{4}$ production under cometabolism, higher inoculum density and thermophilic conditions; higher $\mathrm{CH}_{4}, \mathrm{pH}$ and digestion simultaneously occurred in the mixed-inoculum reactors. A strong relationship between biogas and its $\mathrm{CO}_{2}$ and $\mathrm{CH}_{4}$ main components was found. Horse inoculum in the mixed reactors enhanced $\mathrm{CH}_{4}$ production; sheep inoculums improved digestibility; and the dog inoculum seemed to neutralize $\mathrm{pH}$. S. cerevisiae may have improved cellulolytic activity in FVW digestion at 25 and $39{ }^{\circ} \mathrm{C}$, and provided an energy and nutrient source at $55^{\circ} \mathrm{C}$.
\end{abstract}

(c) 2016 Elsevier Ltd. All rights reserved.

\section{Introduction}

The anaerobic digestion (i.e., AD) is an alternative to landfilling dog feces and fruit and vegetable waste (FVW). The global amount of the latter is immense (>650 million tonnes per year; FAO, 2013), difficult to estimate (Parfitt et al., 2010) and certainly rising (Hall et al., 2009). As to domestic animal feces they are egressed by nearly 1 billion dogs worldwide (Gompper, 2014) as well as 50 billion head of livestock (Goodland and Anhang, 2009).

Compared to landfills, $\mathrm{AD}$ of animal and food waste reduces greenhouse gas emissions $\left(\mathrm{CO}_{2}\right.$ and $\left.\mathrm{CH}_{4}\right)$, landfill fires, acidic leachates and ensuing (ground)water contamination, proliferation of pathogens and their vectors, and mixing of antibiotic multiresistance genes. The $\mathrm{AD}$ of water and animal waste at

\footnotetext{
* Corresponding author.

E-mail address: asalem70@yahoo.com (A.Z.M. Salem).
}

thermophilic temperatures is feasible and effective in inactivating pathogens (WHO, 2012), reducing odors and effluent solids (Metcalf \& Eddy, 2003).

In addition, $\mathrm{AD}$ generates energy as $\mathrm{CH}_{4}, \mathrm{CO}_{2}$ (used in green chemistry and fungi production) and a low-cost fertilizer without aerobic pathogens. Biomethane can be used to increase the temperature of the $A D$ reactors optimizing the process and reducing energy costs. Methane is safe if contained in a sealed environment. As to biomethane combustion, it is deemed carbon-neutral $\mathrm{CO}_{2}$, since its carbon emissions balance out a recent atmospheric $\mathrm{CO}_{2}$ uptake by plants (Ward et al., 2008). Biomethane combustion can substitute fossil fuels and biofuels, thus reducing, among others, polycyclic aromatic hydrocarbons, organometal(loid)s, radionuclides, and smog and acid rain compounds. AD of herbivore and food waste has been previously studied but information on the usefulness of inoculum from dog feces is needed, or on the possible thermophilic inactivation of pathogens which afflict monogastric mammals living in close contact, such as humans and dogs. 
The 30-90 day startup is the most critical step of an AD system (Zhu et al., 2014) during which adaptation and regeneration of the inoculated microbial communities take place (Shen et al., 2013). However, the first hours (initiation) of $\mathrm{AD}$ have seldom been researched.

Here, AD improvements tried to emulate the highly diverse mammalian digestive tract. The process started with the collection of feces from (ruminant and non-ruminant) mammals and the extraction of inoculum to study cometabolism, or biodiversityaugmented microbial digestion. In cometabolism, a consortium of different species transforms organic compounds faster than individual species, because one species produces intermediate byproducts that are needed by others (Islas-Espinoza et al., 2012). Therefore, a consortium of three different anaerobic microbiomes supplemented with $S$. cerevisiae was tested to evaluate AD cometabolism. Sheep, horse, and dog inoculums were expected to bring in biodiversity from ruminant and non-ruminant intestinal microbiomes, to try and cope with rapid acidification brought about by FVW, which inhibits methanogenesis (Shen et al., 2013). In addition to inoculum biodiversity, its quantity is essential, since low abundance of methanogens causes accumulations of volatile fatty acids which can inhibit methanogenic growth and activity, hence a protracted startup (Zhu et al., 2014).

Live yeast (S. cerevisiae) used as feed additive has shown multiple benefits in the rumen: increased acetogenic bacteria, fungi and protozoa (Mao et al., 2014; Hristov et al., 2010), supply of microbial growth factors like organic acids, lipids, proteins, enzymes and vitamins (Chaucheyras et al., 1995; Erasmus et al., 1992), increased cellulolytic activity (Kumar et al., 2013), increased nutrient digestibility and fermentation of fiber (Elghandour et al., 2014; Salem et al., 2015), and oxygen scavenging with improved anaerobiosis (Chaucheyras-Durand et al., 2008).

Liquid $\mathrm{AD}$ takes place below $15 \%$ total solids content and has higher reaction rates hence shorter retention times than solid-state $A D$, agitation is less energy-intensive, and contact is better between microbes and feedstock. Essential to AD is the feedstock to inoculum (F:I) ratio because high F:I lead to overproduction of volatile fatty acids, acidification and inhibition of methanogens (Zhu et al., 2014).

Accordingly, the goal of this research was to assess the effects of cometabolism on key AD parameters (gas production, $\mathrm{pH}$, and digestion).

\section{Material and methods}

\subsection{Sampling}

Fresh samples of dog, sheep and horse feces ( $1.5 \mathrm{~kg}$ per species) were collected once a week in the morning at the State of Mexico University laboratory vivarium and farm to ensure sufficient inoculum quantities. The dogs were $13 \mathrm{~kg}$ mean body weight, 3-yearold beagles; the horses $425 \mathrm{~kg}$ BW, 13-year-old quarter; and the sheep $70 \mathrm{~kg}$ BW, 1-year-old finnsheep. None of the animals had received vaccines, antibiotics or antiparasitics at the time of collection of feces. To minimize exposure of the inoculum to air oxygen and litter material, composite dog feces were collected immediately upon defecation following the morning meal. Horse manure was collected from the intestine with a palpation glove. Sheep morning feces were collected immediately upon defecation. Inoculum density was defined as the amount of fresh microbial biomass extracted from 10 or $25 \mathrm{~g}$ of fresh mammal feces. Inoculum density was used to explore F:I effects. The fecal samples (10 or $25 \mathrm{~g}$ $\mathrm{w} / \mathrm{w})$ were stirred in $(\mathrm{pH} 6.9)$ distilled water to obtain a $50 \mathrm{~mL}$ dilution; from this homogenate the inoculums were extracted by filtration through gauze layers to obtain a fluid fraction free of particles larger than $1 \mathrm{~mm}$.

The feedstock was a mixture of kitchen waste from three university canteens (vegetables and fruits only). The mixture was oven-dried for $48 \mathrm{~h}$ at $50{ }^{\circ} \mathrm{C}$ to avoid volatilization of nitrogen compounds and ground to $1 \mathrm{~mm}$ particle size, in a $0.25 \mathrm{HP}$ dry matter (DM) General Electric mill, at $1725 \mathrm{rpm}$.

\subsection{Processing}

Each $150 \mathrm{~mL}$ bioreactor contained a $50 \mathrm{~mL}$ mixture of $10 \mathrm{~g}: 39 \mathrm{~mL}: 1 \mathrm{~g}$ or $25 \mathrm{~g}: 24 \mathrm{~mL}: 1 \mathrm{~g}$ diluted inoculum, distilled water and FVW, respectively. Headspace to contain biogas was $100 \mathrm{~mL}$. Each bioreactor also received $2.0 \mathrm{mg}$ of live $S$. cerevisiae yeast (Procreatin 7, Safmex/Fermex, Toluca, Mexico, in powder containing $1 \times 10^{10}$ cells $/ g$ ). Each sample was flushed with $\mathrm{CO}_{2}$ for $8 \mathrm{~min}$ to diminish the oxygen concentration and mix FVW and inoculum, and then transferred to the bioreactors closed with Vacutainer stoppers.

The bioreactors $(n=72)$ were divided among eight treatments with three replicates: four inoculum types (dog, sheep, horse and an equal-parts mixture), and two inoculum densities. The procedure was performed at three temperatures $\left(25,39\right.$ and $\left.55^{\circ} \mathrm{C}\right)$.

The bioreactors were transferred to a temperature-controlled PolyScience model $28 \mathrm{~L}$ water bath and incubated for $96 \mathrm{~h}$. Total biogas pressure was measured with a needle-equipped manometer (407,910 differential pressure manometer, Extech Instruments, Waltham, MA, USA) every $2 \mathrm{~h}$ until hour 12 , and then at 18, 24, 36, 48, 72 and $96 \mathrm{~h}$, while $\mathrm{CH}_{4}$ and $\mathrm{CO}_{2}$ were extracted with a $(5 \mathrm{~mL})$ syringe and introduced into an industrial gas detector (Gas-Pro Analyzer, Crowcon, Abingdon, UK). After each gas measurement, all remaining gas was purged from each bottle to minimize disturbance of the fermentation process by dissolution of gases into the liquid. At the end of each experiment, $\mathrm{pH}$ was measured to assess possible inhibition or continuation of AD.

Following $96 \mathrm{~h}$, the fermentation process was stopped, the bottles unstoppered and $\mathrm{pH}$ measured using a $\mathrm{pH}$ meter ( $\mathrm{pH} 15$ Model, Conductronic, Puebla, Mexico); the contents of each bottle were filtered out, dried at $65{ }^{\circ} \mathrm{C}$ for $24 \mathrm{~h}$, and then compared with the initial DM weight. This was done to assess the biodegradability of FVW and to relate digestion.

\subsection{Data analysis}

Biogas, $\mathrm{CO}_{2}$ and $\mathrm{CH}_{4}$ measurements in PSI, percentage of $\mathrm{CO}_{2}$ and percentage of lower explosive limit (\%LEL) were transformed into IS units (mL/g DM) following El-Mashad and Zhang (2010) and Theodorou et al. (1994). The latter is a relatively simple method, which was combined here with an industrial gas detector rather than the more complex apparatus involving gas chromatography, to provide a rapid assessment method.

One-way Anova with post hoc tests and three-way Anova helped assess differences between treatments and interactions among variables $(p<0.05)$. Multiple linear regression was used to identify conditions leading to faster accumulation of gases, $\mathrm{pH}$ changes and feedstock digestion. Principal components analysis helped to identify the main sources of variance among samples and treatments and so, guide the regression analyses. These analyses were carried out using SPSS v12. Kinetic models were fitted to the time series data using Excel 2013. Part of the rapid assessment method, predictive models fitted to early observation of key parameters can inform timely operation decisions, reducing the need for posterior monitoring of a wide array of AD variables. 


\section{Results}

The $\mathrm{p}$ values of the temperature main effect (i.e., 25, 39 and $55{ }^{\circ} \mathrm{C}$ ) and inoculum type (dogs, horses and the sheep) or their interactions are shown in Table 1. One third (20/72) of the samples produced $\mathrm{CH}_{4}$ in the first four days, with isolated pulses of $\mathrm{CH}_{4}$, was the most frequent mode of emission, and flukes of intense release in the most productive treatments. $\mathrm{CH}_{4}$ production started by hour 2 ; most production took place in two bursts between hours 6-12 and hours 36-96; the maximum peak was $0.9759 \mathrm{~mL} \mathrm{CH}_{4} / \mathrm{g}$ DM. between hours 8 and 10 .

\subsection{Cometabolism}

The mixture of inoculums from all three mammals showed enhanced $\mathrm{CH}_{4}$ production suggestive of cometabolism (Figs. 1a, b and $2 \mathrm{~b}$ ). A majority of $\mathrm{CH}_{4}$-producing samples involved high inoculum densities (extracted from $25 \mathrm{~g}$ feces) and mixed inoculums, both of which likely augmented microbial diversity (Fig. 1a). Most $\mathrm{CH}_{4}$-producing samples (Fig. 1a) occurred at 39 and $55{ }^{\circ} \mathrm{C}$, while $\mathrm{pH}$ closer to neutrality ocurred at mesophilic temperature $\left(39^{\circ} \mathrm{C}\right)$ typical of mammalian physiology (Fig. 1d).

Horse inoculum seemed to help increase the frequency of samples that produced $\mathrm{CH}_{4}$ and decreased biogas (Figs. 1a and 2a), while sheep inoculums helped increase FVW digestion (Fig. 2b). As to dog inoculum, it seemed endowed with a buffering capacity (Fig. 1c and d). This was particularly noticeable with high-density dog and mixed inoculums (Fig. 1c). Furthermore, dog inoculum (samples beyond pH 5.5 in Fig. 1d) reversed the usual relationship between $\mathrm{CO}_{2}$ and acidification, while herbivore samples without dog inoculum $(53,55-60$ in Fig. 1d) led to more acidic media with lesser $\mathrm{CO}_{2}$ production.

\subsection{Optimality}

Cometabolism seemed to lead to a $\mathrm{CH}_{4}, \mathrm{pH}$ and digestion optimum. Again this hinged on higher temperatures, inoculum densities and mixed inoculums (Fig. 3a and b). The process may have benefitted in a non-linear way, since $\mathrm{CH}_{4}$ could not be predicted based on the parameters studied here. Under these optimal conditions, one advantage of $55{ }^{\circ} \mathrm{C}$ was the potential for disinfection of several pathogens (Tchobanoglous et al., 1993- Table 2); one disadvantage could be the inactivation of $S$. cerevisiae and its possible use as carbon or nutrient source only.

\subsection{Kinetics}

Patterns of gas accumulation were modeled for the Grand Total of 72 samples, a $55{ }^{\circ} \mathrm{C}$ reactor consisting of 24 samples, the seven $\mathrm{CH}_{4}$-pH optimal samples, and the sample 72 reactor with thermophilic, mixed, high-density inoculum. Based on goodness-of-fit and non-linear regression coefficients (Fig. 4a and b), biogas and $\mathrm{CH}_{4}$ kinetics predicted maximal $\mathrm{CH}_{4}$ volume ratios of $55-80 \%$ in the biogas between 154 and $164 \mathrm{~h} \mathrm{(pH-CH}$ optima; 4 samples at $39^{\circ} \mathrm{C}$, and 3 at $55^{\circ} \mathrm{C}$ ) and $200-210 \mathrm{~h}\left(55^{\circ} \mathrm{C}\right.$ samples).

Biogas accumulation could be understood as a linear curve with 2 parameters: initial value and growth rate of $\ln$ (biogas). Both biogas and $\mathrm{CO}_{2}$ could be modeled as two linear segments: a steep slope until hour 10 and a plateau thereafter (Fig. 4a). Meanwhile, the $\mathrm{CH}_{4}$ accumulation curve was exponential with a vertical asymptote eventually given by the remaining 35\% available FVW. The non-linearity and kinks resulting from slackening and acceleration in $\mathrm{CH}_{4}$ accumulation proved more difficult to fit.

The Grand Total accumulated biogas and $\mathrm{CO}_{2}$ were $2-33$-fold higher and 2-30-fold higher, respectively, then the other pooled reactors. Grand Total $\mathrm{CH}_{4}$ was only 1 or 2 -fold that of other pooled reactors, because fluke $\mathrm{CH}_{4}$ production in sample 72 explained $63-77 \%$ of the other reactors. In other words, sample 72 's $\mathrm{CH}_{4}$ fraction of biogas was $16 \%$ compared to $1-3 \%$ in the other reactors. $\mathrm{CO}_{2}$ was $25 \%$ of biogas in the Grand Total reactor and $1-13 \%$ in the other reactors.

\subsection{Predicting key parameters}

Final biogas accumulations were also predictable as a function of experimental (temperature, inoculum type and density) and output variables (gases, $\mathrm{pH}$ and digestion).

The best regression models (in terms of goodness-of-fit and compliance of assumptions) confirmed the strong relationship between biogas and its $\mathrm{CO}_{2}$ and $\mathrm{CH}_{4}$ components, and all the gases could be predicted from each other as they were somewhat linearly interrelated. Contrariwise, a relationship between $\mathrm{pH}$ and $\mathrm{CO}_{2}$ was not found.

Two valuable models were biogas $=\mathrm{f}$ (temperature, $\mathrm{pH}$ ) as well as $\mathrm{pH}=\mathrm{f}$ (temperature, inoculum animal, biogas). Biogas increments of one $\mathrm{mL} / \mathrm{g}$ DM were linked to 0.628 and 0.772 increments in temperature and $\mathrm{pH}$, respectively. These models however did not accurately represent biogas accumulation under psychrophilic $\left(25^{\circ} \mathrm{C}\right)$ conditions (Fig. 5a and b). As to pH increases of one unit, they were linked to a 0.763 decrease in temperature and one-unit increase in biogas. $\mathrm{CO}_{2}$ increments by one unit could

Table 1

Three-way Anova significant (p-values) main effects and interactions.

\begin{tabular}{|c|c|c|c|c|c|c|c|}
\hline & Temperature & $\begin{array}{l}\text { Inoculum type } \\
\text { (mammal) }\end{array}$ & $\begin{array}{l}\text { Inoculum } \\
\text { density }\end{array}$ & $\begin{array}{l}\text { Temperature } \mathrm{x} \\
\text { mammal }\end{array}$ & $\begin{array}{l}\text { Temperature } \mathrm{x} \text { inoculum } \\
\text { density }\end{array}$ & $\begin{array}{l}\text { Temperature } \mathrm{x} \text { mammal } \mathrm{x} \\
\text { inoculum density }\end{array}$ & $\begin{array}{l}\text { Mammal x inoculum } \\
\text { density }\end{array}$ \\
\hline Biogas & $25^{\circ} \mathrm{C}$ & $\operatorname{dog} \neq$ herbivores & d & 0.000 & 0.000 & 0.000 & 0.000 \\
\hline $\mathrm{CO}_{2}$ & $\begin{array}{l}\text { all } \\
\text { temperatures }\end{array}$ & $\operatorname{dog} \neq$ horse & $(1: 1 \neq 1: 4)^{\mathrm{a}}$ & & 0.028 & & 0.004 \\
\hline $\mathrm{CH}_{4}$ & $\begin{array}{l}\text { all } \\
\text { temperatures } \\
\text { : }\end{array}$ & & & & & & \\
\hline Digestion & $25 \neq 55^{\circ} \mathrm{C}$ & $\begin{array}{l}\operatorname{mix} \neq \text { horse, } \operatorname{mix} \neq \\
\text { dog }\end{array}$ & & 0.001 & & & 0.004 \\
\hline $\mathrm{pH}$ & $39 \neq 55^{\circ} \mathrm{C}$ & $\begin{array}{l}\text { All different but } \\
\text { sheep = horse }\end{array}$ & $(1: 1 \neq 1: 4)^{b}$ & 0.000 & 0.000 & 0.000 & 0.000 \\
\hline
\end{tabular}

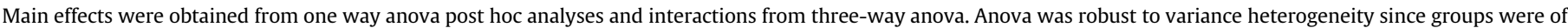
equal size.

a $\mathrm{CO}_{2}: \mathrm{p}$ value $=0.071$

b $\mathrm{pH}$ : p value $=0.052$

c In three-way anova, no $\mathrm{CH}_{4}$ differences were due to main effects or interactions.

d In three-way anova, i.e. simultaneously considering interactions, inoculum density differences were linked to significant differences in biogas ( $\mathrm{p}<0.000$ ). 


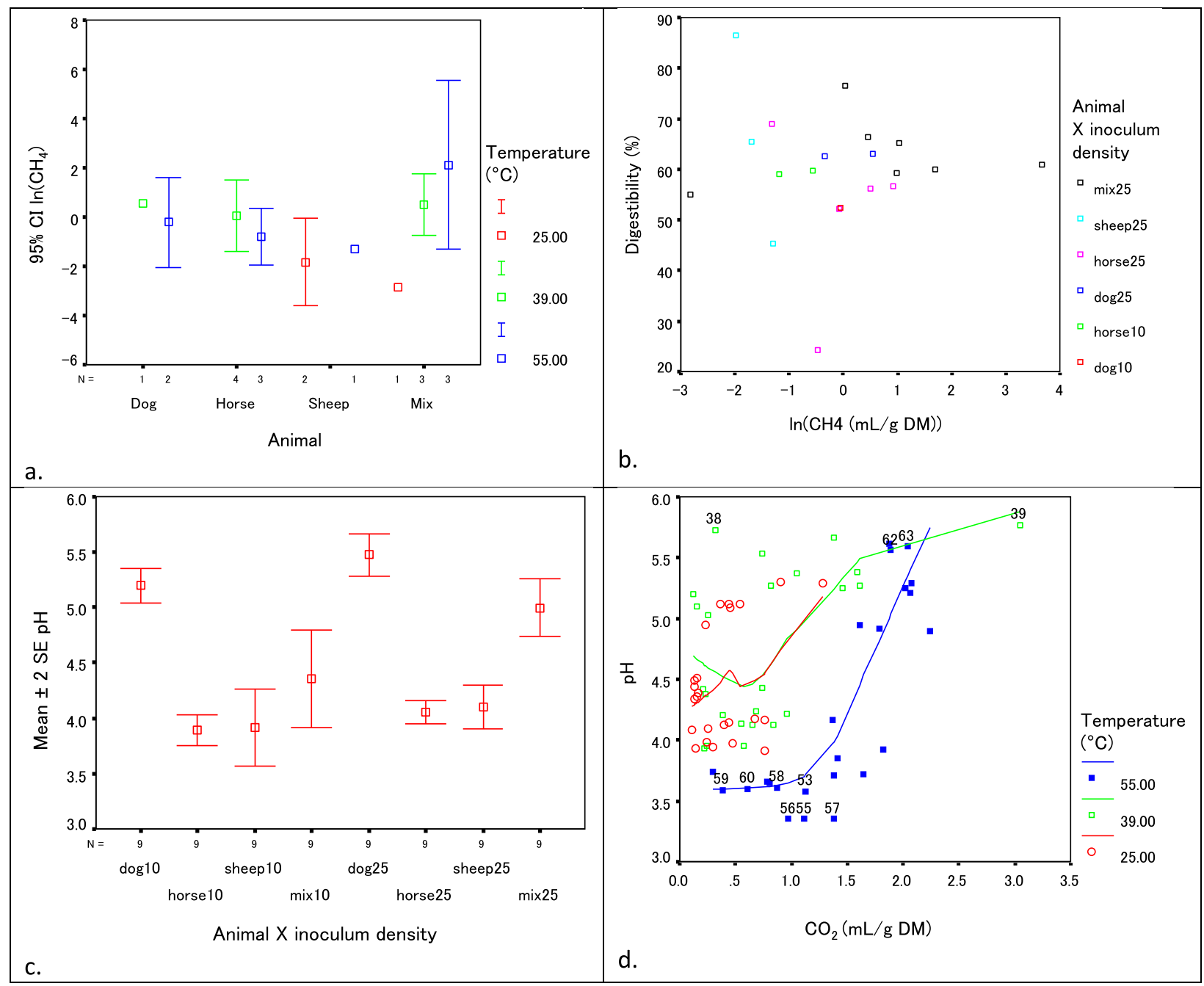

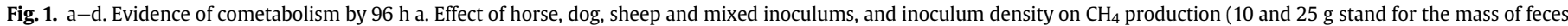

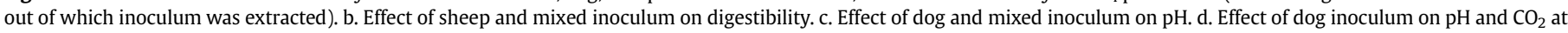
39 and $55^{\circ} \mathrm{C}$.

also be predicted by temperature and biogas increments of 0.383 and 0.496 respectively.

However, non-linearity and the kinks attributable to $\mathrm{CH}_{4}$ pulses and flukes (Fig. 4b), as well as the absence of significant effects or interactions explaining $\mathrm{CH}_{4}$ (in anova), made $\mathrm{CH}_{4}$ more difficult to predict as a linear function of other variables (Table 1 ).

Turning to the role of temperature, its effects (on gases including $\mathrm{CH}_{4}, \mathrm{pH}$, and digestion) were significant both directly and through interactions. Furthermore, only temperature explained final $\mathrm{CH}_{4}$ accumulation differences; other variables and interactions among temperature, density and type of inoculum did not lead to significant $\mathrm{CH}_{4}$ accumulation differences ((Table 1).

\section{Discussion}

In this study, the influence of temperature, inoculum density and cometabolism on $\mathrm{AD}$ degradation of $\mathrm{FVW}$ and $\mathrm{CH}_{4}$ generation were explored. The initiation of anaerobic reactors is critical for a reduced startup period, which can be a convincing feature toward an increased number of $\mathrm{AD}$ users for waste treatment and energy generation. Another factor of increased use of AD can be the timely prediction of digestion and methane generation rates via rapid assessment of key AD variables ( $\mathrm{pH}$ and temperature).
The rapid method also yielded data on methane generation features during the initiation period (pulses, flukes or bursts, see Islas-Espinoza, 2016 online data). They were probably not artefactual since $\mathrm{CH}_{4}$ pulses and bursts are also observable in vivo during eructation in ruminants and monogastric mammals. As for any method, caveats existed, such as a lower detection limit equivalent to $0.938 \mathrm{~mL} \mathrm{CH}_{4} / \mathrm{g}$ DM and an upper $\mathrm{CO}_{2}$ detection limit of $9.99 \%$ of biogas which may call for sensitivity analyses of $\mathrm{CO}_{2}$ kinetics.

\subsection{Anaerobic cometabolism}

Cometabolism is a hitherto little studied process. Here, inoculum diversity in combination with higher inoculum density seemed to enhance $\mathrm{CH}_{4}$ production, $\mathrm{pH}$ and digestion. Inoculum selection is a key to stable AD operation and stress tolerance (De Vrieze et al., 2015) and could in future be complemented by cometabolism and high inoculum concentration (Tasnim et al., 2016).

The most intense $\mathrm{CH}_{4}$ production events occurred with more diverse inoculum. This diversity is due to the selection of digestion genes and enzymes in different domestic animals reared and fed in consistent and narrowly defined ways (Hanning and Diaz-Sanchez, 2015). Here we assembled a diverse gastrointestional microbiome and exposed it to FVW feed and digestion conditions different from 


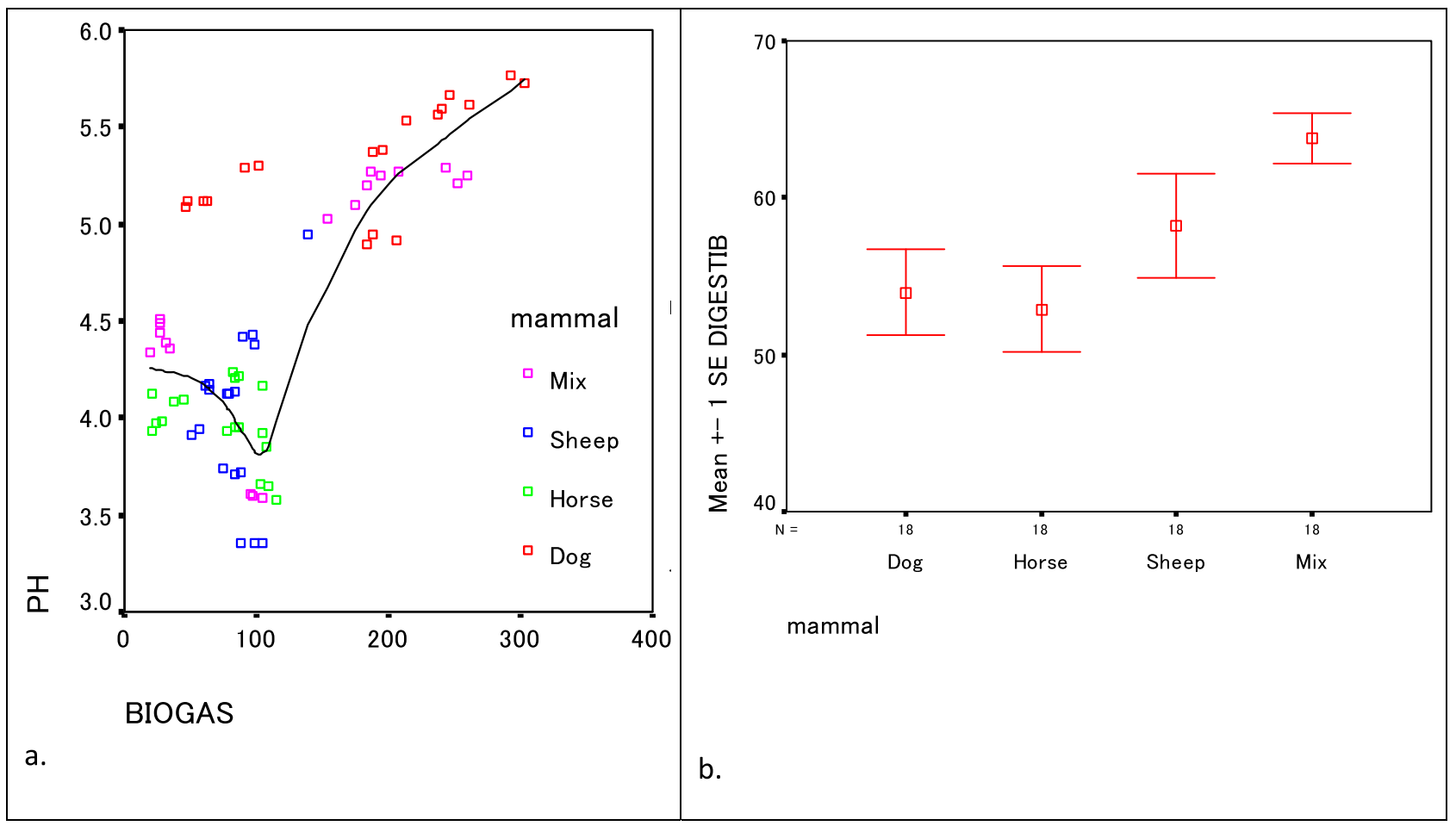

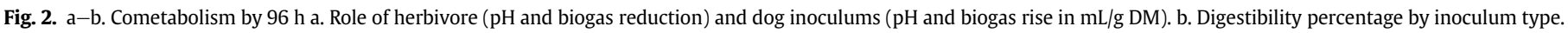

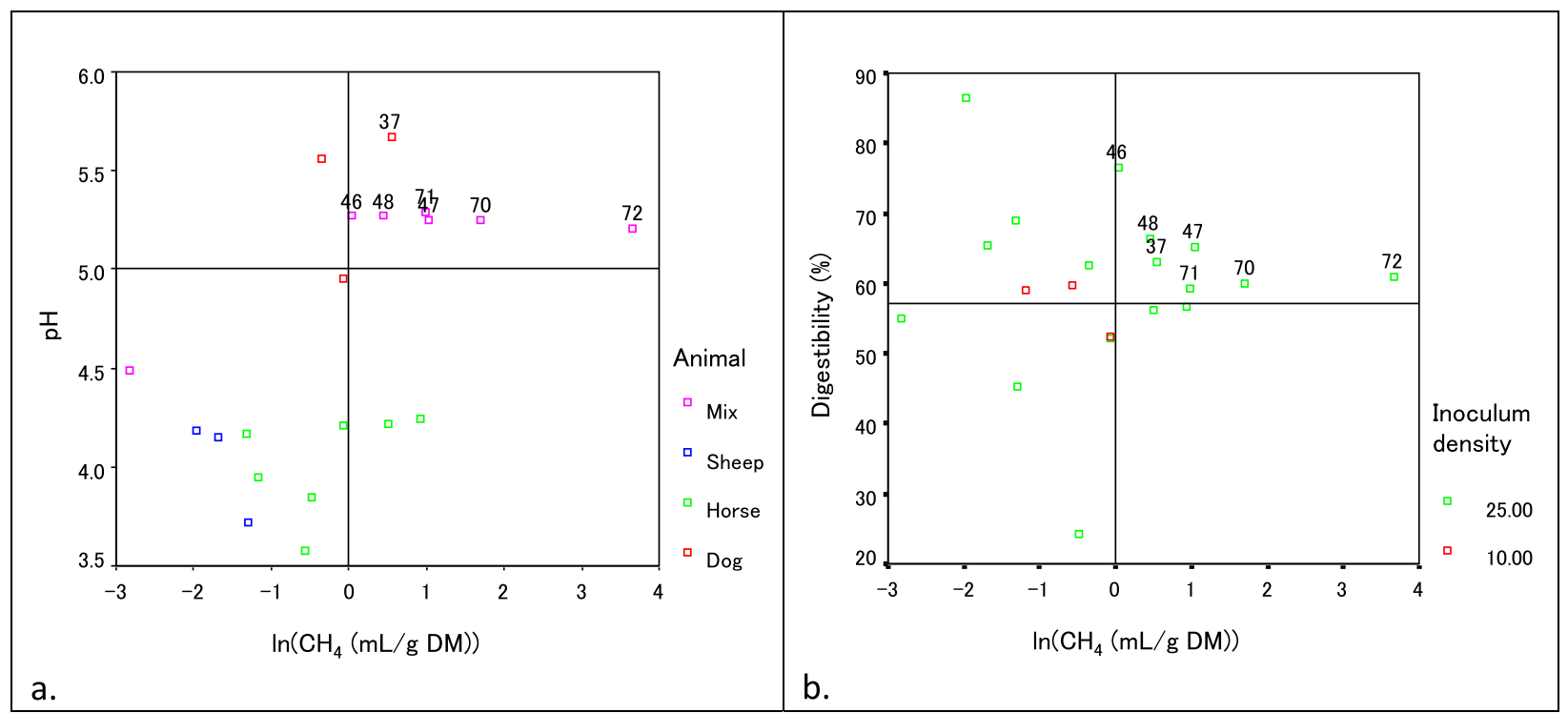

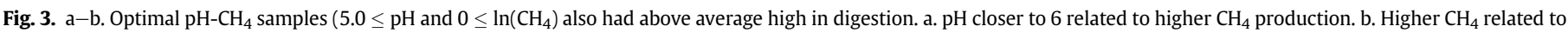
higher digestibility.

in vivo studies on animal $\mathrm{CH}_{4}$ production. This made the fibrolytic and cellulotic advantages of horse and sheep inoculum difficult to compare with other studies. As to the buffering capacity of dog inoculum, it deserves more attention; it had escaped notice despite ongoing interest dedicated to buffering capacity, which may be linked to a comparatively more alkaline digestive tract in dogs $(\mathrm{pH}$ 7.3). The fact that higher inoculum density did not seem to improve digestion, except when interacting with dog inoculum, confirmed the importance of the latter.

As to the role of yeast extract as carbon source in initiation of cometabolism (Islas-Espinoza et al., 2012), it was more likely at $55{ }^{\circ} \mathrm{C}$, a temperature which allowed for only minimal survival of yeast, since $S$. cerevisiae is mostly inactivated at $55{ }^{\circ} \mathrm{C}$ (Reveron et al., 2003). At lower temperatures, S. cerevisiae might have enhanced biodiversity. Other benefits from yeast might have occurred at all temperatures. In particular, Desnoyers et al. (2009) show increased $\mathrm{pH}$ and digestibility due to $S$. cerevisiae supplementation in a meta-analysis on ruminants.

Kinetics-wise, during the initiation period, Gompertz curves often used to model the startup period, could fit cumulative biogas 
Table 2

Disinfection of several pathogens at $45-55^{\circ} \mathrm{C}$.

\begin{tabular}{ll}
\hline Organism & Required exposure (minutes) \\
\hline Salmonella typhosa & 30 \\
Salmonella sp. & 60 \\
Shigella sp. & 60 \\
Escherichia coli & 60 \\
Entamoeba hystolitica cysts & A few mn @45 ${ }^{\circ} \mathrm{C},<1 @ 55^{\circ} \mathrm{C}$ \\
Taenia saginata & A few mn \\
Trichinella spiralis & Quickly \\
Brucella abortus & 60 \\
Micrococcus aureus pyogenes & $10 \mathrm{mn} @ 50^{\circ} \mathrm{C}$ \\
Streptococcus pyogenes & $10 \mathrm{mn} @ 54{ }^{\circ} \mathrm{C}$ \\
Corynebacterium diphtheriae & 45 \\
Nacator americanus & $50 @ 45{ }^{\circ} \mathrm{C}$ \\
Ascaris lumbricoides eggs & 60
\end{tabular}

Source: Gotaas HB, composting sanitary disposal and reclamation of solid wastes, WHO, Geneva 1956, cited in Tchobanoglous et al. (1993) Integrated solid waste management. Engineering principles and management issues, McGraw Hill, Inc. Note: The $55{ }^{\circ} \mathrm{C}$ threshold is used in particular in aerobic compost processes to reduce pathogens in US EPA (1979).
Despite an increased energy requirement to attain thermophilic conditions, this allows for disinfection of a number of known pathogens (pathogens of Table 2) in effluent water and biosolid after AD. This can entail just the inconvenient of significantly lower $\mathrm{pH}$ compared to mesophilic physiological temperature. In comparison, few processes seemed to benefit from a psychrophilic environment.

\subsection{Acidification}

Acidification was widespread in all the bioreactors, however, more temperature, inoculum and biodiverse inoculum led to optimal $\mathrm{CH}_{4}-\mathrm{pH}$. Explanations of the rapid acidification might hinge on the following. $\mathrm{CO}_{2}$ flushing as premixing strategy may have accelerated the acidification process: $\mathrm{CO}_{2}$ partial pressure produced by fermentation solubilizes $\mathrm{CO}_{2}$ in water yielding carbonic acid which consumes alkalinity (Metcalf \& Eddy, 2003). Also, if an organic compound is oxidized, two hydrogen atoms are

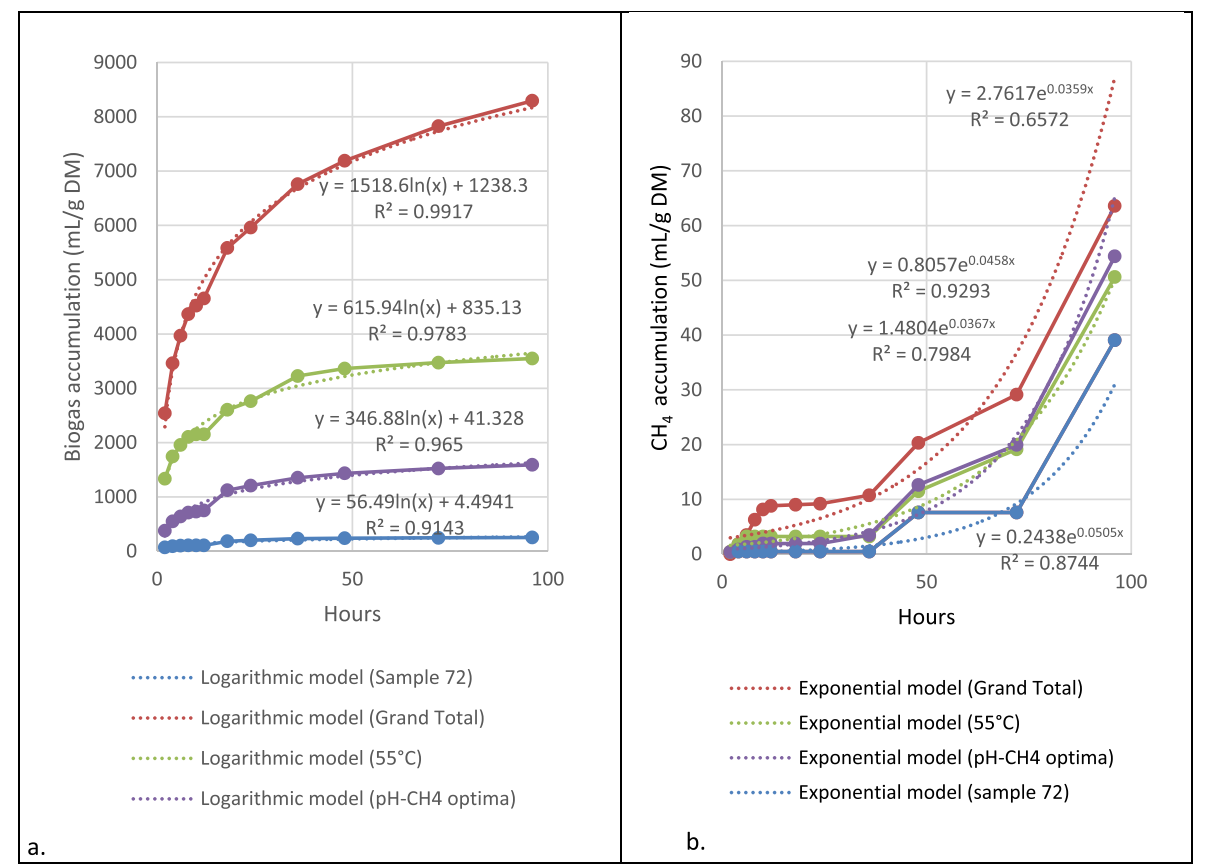

Fig. 4. a-b. Kinetics of biogas (deceleration) and $\mathrm{CH}_{4}$ (acceleration). a. Cumulative biogas kinetics. b. Cumulative $\mathrm{CH}_{4}$ kinetics.

kinetics but not the early onset of exponential methanogenesis. $\mathrm{CH}_{4}$ accelerated while $\mathrm{CO}_{2}$ decelerated suggesting that $\mathrm{CO}_{2}$ might have been transformed directly to $\mathrm{CH}_{4}$ by hydrogenotrophic methanogens or indirectly to acetate and then to $\mathrm{CH}_{4}$ by acetotrophic methanogens.

\subsection{Thermophilic conditions}

Inoculum from mesophilic digestive-tract communities was used successfully to initiate thermophilic $\mathrm{AD}$, a procedure called aggressive startup (Griffin et al., 1998). Temperatures of $25^{\circ} \mathrm{C}$ and $55{ }^{\circ} \mathrm{C}$ probably were drastic treatments which modified the biodiversity prevalent at physiological temperature in mammalian intestines. In relation to $\mathrm{CH}_{4}$ production, among the controlled variables only temperature brought about significant $\mathrm{CH}_{4}$ accumulation differences. This is consistent with several studies where higher temperatures accelerate AD (Jain et al., 2015). released to an electron carrier and then to a permanent electron acceptor (Gaudy and Gaudy, 1981); if an acceptor is not available, for instance due to insufficient presence of hydrogenotrophic methanogens, the hydrogen release may be a source of acidification.

However, $\mathrm{CO}_{2}$ flushing as premixing strategy may have led to good feedstock-inoculum mixture and significantly improved AD performance (Zhu et al., 2014). In addition, 12 times faster methanogenesis is carried out by $\mathrm{CO}_{2}$-reducing methanogens compared to other methanogens (Zinder et al., 1984). This may have coincided with the buffering capacity noticed in dog and mixed inoculum samples. S. cerevisiae supplementation may have removed oxygen from the reactors and improved cellulolytic activity at 25 and $30^{\circ} \mathrm{C}$, accelerating the $\mathrm{CH}_{4}$ production.

Finally, anaerobic cometabolism with dog, horse and sheep inoculums and the use of FVW and S. cerevisiae seem to hold a potential for economical and sustainable methane generation as 


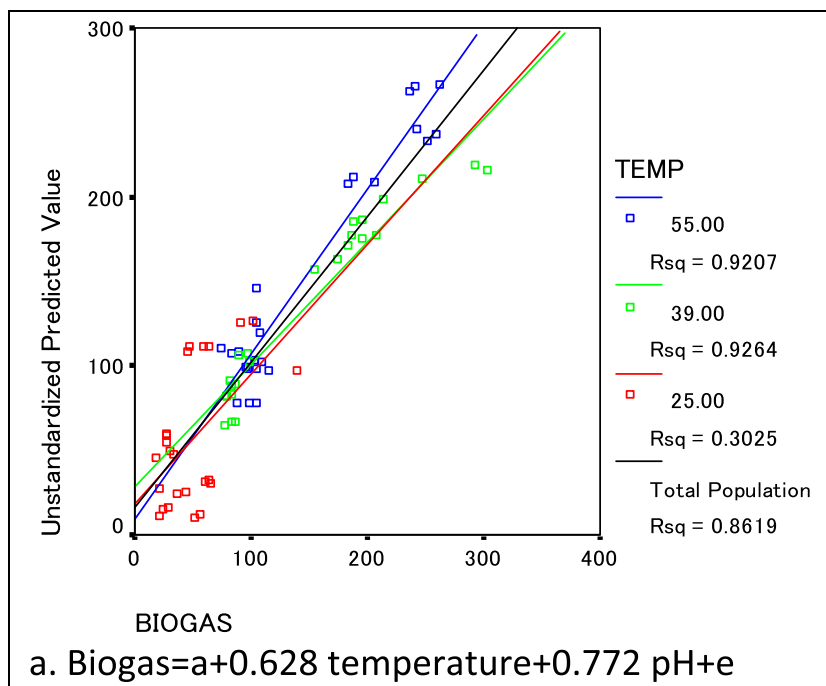

a. Biogas $=a+0.628$ temperature $+0.772 \mathrm{pH}+\mathrm{e}$

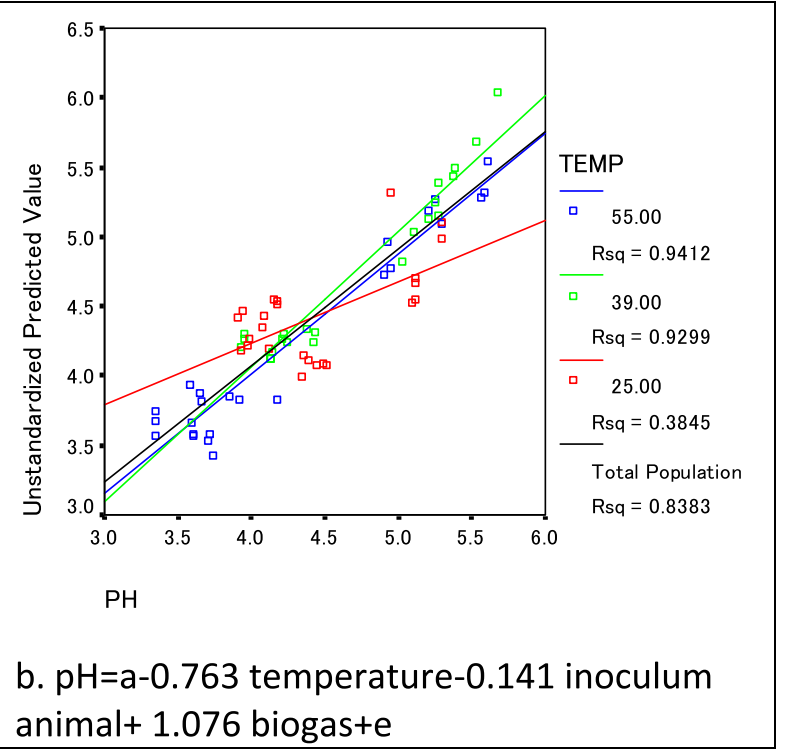

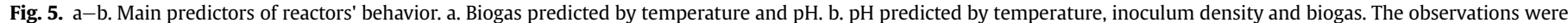
also located around the diagonal of the plots denoting neither systematic overestimates nor underestimates. Rsq is the determination coefficient.

source of energy, and a potential to reduce pollution and healthrelated issues.

\section{Conclusions}

The $\mathrm{AD}$ is a biological process that can produce biomethane as energy source, using FVW waste as substrate. Cometabolism proved to be a novel way to enhance liquid $A D$, via augmenting the biodiversity of inoculums with dog, horse and sheep feces, as well as, in the initial period, live yeast. Thermophilic and mesophilic conditions, coupled with cometabolism and higher inoculum density enhanced $\mathrm{CH}_{4}$ generation and improved $\mathrm{pH}$ and digestion. Horse inoculum in the mixed reactors seemed to enhance $\mathrm{CH}_{4}$ production; sheep inoculum to improve digestibility; and dog inoculum and $S$. cerevisiae to raise $\mathrm{pH}$ toward neutrality. Therefore, anaerobic cometabolism of FVW may hold a strong potential for clean energy generation and waste reduction.

\section{References}

Chaucheyras, F., Fonty, G., Bertin, G., Gbuet, P., 1995. Effects of live Saccharomyces cerevisiae cells on zoospore germination, growth, and cellulolytic activity of the rumen anaerobic fungus, Neocallimastix frontalis $\mathrm{MCH}$ 3. Curr. Microbiol. 31, 201-205.

Chaucheyras-Durand, F., Walker, N.D., Bach, A., 2008. Effects of active dry yeasts on the rumen microbial ecosystem: past, present and future. Anim. Feed Sci. Technol. 145, 5-26.

Desnoyers, M., Giger-Reverdin, S., Bertin, G., Duvaux-Ponter, C., Sauvant, D., 2009 Meta-analysis of the influence of Saccharomyces cerevisiae supplementation on ruminal parameters and milk production of ruminants. J. Dairy Sci. 92, $1620-1632$.

De Vrieze, J., Gildemyn, S., Vilchez-Vargas, R., Jáuregui, R., Pieper, D.H., Verstraete, W., Boon, N., 2015. Inoculum selection is crucial to ensure operational stability in anaerobic digestion. Appl. Microbiol. Biotechnol. 99, 189-199.

Elghandour, M.M.Y., Vázquez Chagoyán, J.C., Salem, A.Z.M., Kholif, A.E., Martínez Castañeda, J.S., Camacho, L.M., Buendía, G., 2014. In vitro fermentative capacity of equine fecal inocula of nine fibrous forages in presence of different doses of Saccharomyces cerevisiae. J. Equine Veterinary Sci. 34, 619-625.

Erasmus, L.J., Botha, P.M., Kistner, A., 1992. Effect of yeast culture supplement on production, rumen fermentation and duodenal nitrogen flow in dairy cows. J. Dairy Sci. 75, 3056-3065.

El-Mashad, H., Zhang, R., 2010. Biogas production from co-digestion of dairy manure and food waste. Bioresour. Technol. 101, 4021-4028.

EPA, 1979. Criteria for classification of solid waste disposal facilities and practices. Federal Register 44.

FAO, 2013. Food Wastage Footprint. Impact on Natural Resources. Summary Report
FAO, Rome, p. 12.

Gaudy, A., Gaudy, E., 1981. Microbiology for Environmental Scientists and Engineers. McGraw Hill Kogakusha, Tokyo.

Gompper, M.E., 2014. The dog-human-wildlife interface: assessing the scope of the problem. In: Gompper, M.E. (Ed.), Free-ranging Dogs and Wildlife Conservation. Oxford University Press, Oxford.

Goodland, R., Anhang, J., 2009. Livestock and Climate Change. What if the Key Actors in Climate Change Were Pigs, Chickens and Cows? Worldwatch November/December 2009. Worldwatch Institute, Washington, DC, USA, 10 pp.

Griffin, M.E., McMahon, K.D., Mackie, R.I., Raskin, L., 1998. Methanogenic population dynamics during start-up of anaerobic digesters treating municipal solid waste and biosolids. Biotechnol. Bioeng. 57, 343-355.

Hall, K.D., Guo, J., Dore, M., Chow, C.C., 2009. The progressive increase of food waste in America and its environmental impact. PLoS ONE 4 (11), e7940. http:// dx.doi.org/10.1371/journal.pone.0007940.

Hanning, I., Diaz-Sanchez, S., 2015. The functionality of the gastrointestinal microbiome in non-human animals. Microbiome 3, 1-11.

Hristov, A.N., Varga, G., Cassidy, T., Long, M., Heyler, K., Karnati, S.K.R., Corl, B., Hovde, C.J., Yoon, I., 2010. Effect of Saccharomyces cerevisiae fermentation product on ruminal fermentation and nutrient utilization in dairy cows. J. Dairy Sci. 93, 682-692.

Islas-Espinoza, M., Reid, B.J., Wexler, M., Bond, P.L., 2012. Soil bacterial consortia and previous exposure enhance the biodegradation of sulfonamides from pig manure. Microb. Ecol. 64, 140-151.

Islas-Espinoza, M., 2016. AD FVW Psychro-, Meso-, and Thermophilic Cometabolism Using Dog, Horse and Sheep Inoculums: Gases, PH and Digestion Data. http:// dx.doi.org/10.7910/DVN/QLPZEB. Harvard Dataverse.

Jain, S., Jain, S., Wolf, I.T., Lee, J., Tong, Y.W., 2015. A comprehensive review on operating parameters and different pretreatment methodologies for anaerobic digestion of municipal solid waste. Renew. Sustain. Energy Rev. 52, 142-154.

Kumar, D.S., Srinivasa Prasad, Ch, Prasad, R.M.V., 2013. Effect of yeast culture (Saccharomyces cerevisiae) on ruminal microbial population in buffalo bulls. Buffalo Bull. 32, 116-119.

Mao, Hui-ling, Mao, Hua-long, Wang, J.K., Liu, J.X., Yoon, I., 2014. Effects of Saccharomyces cerevisiae fermentation product on in vitro fermentation and microbial communities of low-quality forages and mixed diets. J. Anim. Sci. 91, $3291-3298$.

Metcalf \& Eddy, Tchobanoglous, G., Burton, F., Stensel, H.D., 2003. Wastewater Engineering: Treatment and Reuse, fourth ed. McGraw-Hill Education, p. 1819.

Parfitt, J., Barthel, M., Macnaughton, S., 2010. Food waste within food supply chains: quantification and potential for change to 2050. Phil. Trans. R. Soc. B 2010 (365), 3065-3081.

Reveron, I.M., Barreiro, J.A., Sandoval, A.J., 2003. Thermal resistance of Saccharomyces cerevisiae in pilsen beer. J. Inst. Brew. 109, 120-122.

Salem, A.Z.M., Elghandour, M.M.Y., Kholif, A.E., Barbabosa, A., Camacho, L.M., Odongo, N.E., 2015. The effect of feeding horses a high fiber diet with or without live yeast cultures supplementation on feed intake, nutrient digestion, blood chemistry, fecal coliform count and in vitro fecal fermentation. J. Equine Veterinary Sci. 35, 735-743.

Shen, F., Yuan, H., Pang, Y., Chen, S., Zhu, B., Zou, D., Liu, Y., et al., 2013. Performances of anaerobic co-digestion of fruit \& vegetable waste (FVW) and food waste (FW): single-phase vs. two-phase. Bioresour. Technol. 144, 80-85. 
Tasnim, T., Behera, S.K., Zafar, M., Park, H.-S., 2016. Batch anaerobic digestion of simulated Bangladeshi food waste: methane production at different inoculumto-substrate ratios and kinetic analysis. Int. J. Glob. Warm. 9, 95-109.

Tchobanoglous, G., Theisen, H., Vigil, S., 1993. Integrated Solid Waste Management. Engineering Principles and Management Issues. McGraw Hill, Inc.

Theodorou, M., Williams, B., Dhanoa, M., McAllan, A., France, J., 1994. A simple gas production method using a pressure transducer to determine the fermentation kinetics of ruminant feeds. Anim. Feed Sci. Technol. 48, 185-197.

Ward, A.J., Hobbs, P.J., Holliman, P.J., Jones, D.L., 2008. Optimisation of the anaerobic digestion of agricultural resources. Bioresour. Technol. 99, 7928-7940.

WHO, 2012. In: Dufour, Al, Bartram, Jamie, Bos, Robert, Gannon, Victor (Eds.), Animal Waste, Water Quality and Human Health. IWA Publishing, London UK.

Zhu, J., Zheng, Y., Xu, F., Li, Y., 2014. Solid-state anaerobic co-digestion of hay and soybean processing waste for biogas production. Bioresour. Technol. 154, $240-247$.

Zinder, S., Cardwell, S., Anguish, T., Lee, M., Koch, M., 1984. Methanogenesis in a thermophilic $\left(58^{\circ} \mathrm{C}\right)$ anaerobic digestor: Methanothrix sp. as an important aceticlastic methanogen. Appl. Environ. Microbiol. 47, 796-807. 